\title{
Penerapan Metode Student Centered Learning Tipe Small Group Discussion dalam Pembelajaran Fisika Terapan Taruna Teknika Nautika
}

\author{
Lusiani \\ Akademi Maritim Nusantara Cilacap, Cilacap \\ anilusi0287@gmail.com
}

Diterima 31 Januari 2021, direvisi 01 Februari 2021, diterbitkan 08 Maret 2021

\begin{abstract}
Abstrak
Kajian ini bertujuan untuk memberikan gambaran penerapan metode student centered learning tipe small group discussion dalam pembelajaran fisika terapan taruna teknika nautika. Metode pada kajian ini yakni survei serta kajian literatur. Obyek penelitian yaitu taruna program studi teknika dan nautika AMN Cilacap. Hasil belajar pada ranah psikomotorik diperoleh melalui metode diskusi. Instrumen yang digunakan yaitu menggunakan media google classroom. Berdasarkan tampilan pada setiap gambar, dideskripsikan langkah small group discussion pada pembelajaran fisika terapan teknika nautika. Langkah 1 sampai 6 terlihat pada gambar 1 hingga 17. Pada kelas Teknika terlihat pada gambar 3, 4, 7, 8, 9, 10. Sedangkan pada kelas Nautika terlihat pada gambar 5, 6, 11, 12, 13, 14, 15, 16, 17. Pembelajaran fisika terapan pada kelas Nautika lebih antusias dan aktif menggunakan small group discussion, sedangkan pada kelas Teknika terlihat standar (pada umumnya). Setelah dilakukan analisis serta pembahasan, disimpulkan metode student centered learning tipe small group discussion dalam pembelajaran fisika terapan taruna teknika nautika dapat diterapkan sesuai dengan 6 langkah dalam small group discussion.
\end{abstract}

Kata kunci : fisika terapan, student centered learning, small group discussion

\begin{abstract}
This study aims to provide an overview of the application of the student centered learning method type of small group discussion in applied physics learning for nautical engineering cadets. The method in this study is a survey and literature review. The research object was cadets in the engineering and nautical study program of AMN Cilacap. Learning outcomes in the psychomotor domain are obtained through the discussion method. The instrument used is using google classroom media. Based on the appearance of each image, a small group discussion step in the applied physics learning of nautical techniques is described. Steps 1 to 6 are shown in Figures 1 to 17. In the Engineering class, it can be seen in Figures 3, 4, 7, 8, 9, 10. Whereas in the Nautical class, it can be seen in Figures 5, 6, 11, 12, 13, 14, 15, 16, 17. Applied physics learning in the Nautical class is more enthusiastic and active using small group discussions, whereas in the Engineering class it looks standard (in general). After analyzing and discussing it, it was concluded that the student centered learning method of the small group discussion type in applied physics learning by nautical engineering cadets can be applied according to the 6 steps in the small group discussion.
\end{abstract}

Keywords: applied physics, student centered learning, small group discussion 


\section{Pendahuluan}

Pembelajaran dapat dilakukan dalam 2 arah yaitu teacher centered dan student centered. Dalam arah transformasi pendidikan digital, maka student centered merupakan hal yang perlu diterapkan dengan dukungan teknologi dan pendidik yang dapat beradaptasi dengan teknologi. Kemandirian belajar peserta didik diperlukan dalam penguasaan konsep tertentu sehingga dapat menciptakan semangat diri dalam belajar.

Penggunaan metode yang memiliki sifat teacher center ditemukan memiliki dampak terhadap berkurangnya antusias siswa saat proses belajar menajar, selain berdampak pada prestasi belajar. Sesuai dengan hal yang dialami pendidik bahwa penggunaan metode konvensional menjadikan siswa terkesan tidak aktif berdiskusi, bertanya, atau memberikan tanggapan atas soal yang diajukan pendidik. [1]

Peserta didik terlihat aktif saat tertentu saja misal tanya jawab sesuai catatan materi yang telah diberikan pendidik, namun saat kegiatan belajar mengajar peserta didik lebih memilih berinteraksi dengan temannya di luar materi yang seharusnya dibahas, sehingga sedikit yang fokus. Hal tersebut memberikan dampak bahwa saat dilakukan penilaian akhir kegiatan belajar mengajar, diperoleh nilai belum maksimal dari peserta didik. Sehingga menunjukkan peserta didik memiliki penguasaan materi belum maksimal. Terdapat kemungkinan disebabkan kegiatan belajar mengajar bersifat teacher center, peserta didik belum aktif saat kegiatan belajar mengajar, serta peserta didik memiliki pemahaman yang belum maksimal terhadap teori yang dijelaskan tanpa mengalami secara langsung.[2]

Dalam mencapai tujuan kegiatan belajar mengajar dan memberikan dampak berbeda dalam hal ketuntasan nilai peserta didik dalam 3 ranah yakni kognitif, afektif, psikomotorik, bukan hanya model yang memiliki dampak namun dalam menentukan metode serta kaidah kegiatan belajar mengajar Ilmu Pengetahuan Alam yang sesuai yaitu peserta didik mampu mendapatkan secara individu konsep kegiatan belajar mengajar serta keterlibatan secara langsung, maka dipastikan aktif saat kegiatan belajar mengajar. Metode yang dapat diterapkan pada kegiatan belajar mengajar tersebut, dapat digunakan metode diskusi kelompok kecil (Small Group Discussion).[2]

Penerapan model belajar mengajar kooperatif pada kajian berikut yakni model belajar mengajar small group discussion yang termasuk model belajar mengajar individu serta terstruktur yang terdiri dari kelompok kecil sekitar 4 sampai 6 anggota serta mampu menjadikan kegiatan belajar mengajar lebih aktif serta antusias untuk peserta didik dan mampu melibatkan peserta didik secara aktif saat proses belajar mengajar di kelas meskipun pendidik tidak terlihat. [3]

Metode Small Group Discussion adalah salah satu tipe metode diskusi. Small Group Discussion (diskusi kelompok kecil) merupakan sebuah proses yang teratur dengan keterlibatan sekelompok pribadi terdiri dari $3-7$ peserta didik pada sebuah kegiatan tatap muka secara kooperatif.[2]

Small group discussion merupakan proses belajar mengajar dengan cara diskusi kelompok kecil yang bertujuan supaya siswa mempunyai keterampilan pemecahan masalah berkaitan dengan materi inti serta permasalahan yang dialami sehari-hari. Small group discussion dapat memiliki arti proses penglihatan dua maupun lebih pribadi dalam interaksi secara menyeluruh serta saling bertatap muka terhadap sasaran yang telah ditentukan menggunakan cara berbagi informasi, mempertahankan opini maupun pemecahan masalah. Kegiatan belajar mengajar kolaboratif bisa memberikan peluang dalam mencapai ketuntasan pelaksanaakn kegiatan belajar mengajar. Dalam fungsi teknologi dalam kegiatan belajar mengajar (technology for instruction), kegiatan belajar mengajar kolaboratif melibatkan partisipasi aktif peserta didik serta menjadikan perbedaan antar individu menjadi lebih minim. [4]

Berdasarkan beberapa studi literatur tersebut, maka penulis tertarik untuk memberikan gambaran penerapan metode student centered learning tipe small group discussion dalam pembelajaran fisika terapan taruna teknika nautika. Penulis tertarik karena gambaran tersebut dapat dikaitkan dengan hasil belajar serta motivasi belajar dalam arah transformasi digital nantinya, sehingga diharapkan adanya keberlanjutan pola pikir serta variasi strategi serta media pembelajaran pada penelitian selanjutnya. 


\section{Materi dan Metode}

Keterkaitan antar unsur dalam kegiatan belajar mengajar kelompok Small group discussion antara lain:

1. Interaksi ketergantungan positif. Cooperative learning menginginkan terdapat ketergantungan positif saling membantu serta memotivasi hingga terdapat interaksi antara peserta didik.

2. Akuntabilitas individual Small group discussion memiliki tujuan terdapatnya akuntabilitas pribadi yang menilai penguasaan bahan belajar setiap peserta, serta umpan balik hasil belajar anggota lainnya hingga diantaranya saling tahu bagi yang membutuhkan bantuan. Akuntabilitas individual sering diabaikan sehingga tugastugas sering dikerjakan oleh sebagian anggota (kelompok tradisional). Peserta didik wajib mempunyai tanggungjawab pada tugas yang dimiliki setiap anggota pada small group discussion.

3. Tatap muka Small group discussion mewajibkan semua anggota kelompok belajar mampu berhadapan hingga dialog bukan sebatas bersama pendidik namun sesama anggota. Interaksi sejenis ini memberikan kemungkinan peserta didik sebagai sumber belajar antar anggota. Ini dibutuhkan sebab peserta didik sering memiliki rasa lebih mudah belajar dengan sesama anggota dibandingkan dengan pendidik.

4. Ketrampilan Sosial memiliki tujuan pesrta didik dapat diberi bekal beberapa macam ketrampilan sosial antara lain tenggang rasa, sopan santun sesama anggota, meberikan usulan/saran ide, berani mempertahankan pikiran logis, tidak mendominasi lainnya, mandiri, serta sifat lainya yang memberikan manfaat menjaga hubungan antar individu bukan sekedar dianggap namun dengan sadar diberikan.

5. Proses Kelompok, terjadi saat masingmasing anggota memberikan penilaian keefektifan dalam berinteraksi dalam menggapai sasaran secara bersama.
Diperlukan pembahasan perilaku anggota secara kooperatif (kooperatif/non kooperatif) dan memutuskan perlikau yang wajib diperbaiki maupun dipertahankan.

Small group discussion memiliki sasaran untuk ditingkatkan. Sasaran tersebut sebagai berikut:

1. Supaya peserta didik berdiskusi dalam pemecahan masalah secara individu.

2. Supaya peserta didik berdiskusi dalam hal permasalahan yang berkaitan dalam keseharian, dalam lingkungan sekolah sekolah maupun lingkungan sekitarnya.

3. Supaya peserta didik berdiskusi dalam hal pembelajaran dalam kelas yang memiliki tujuan evaluasi sesama terkait pemahaman terhadap materi yang diperoleh, sehingga setiap anggota dapat meningkatkan pemahaman jauh lebih baik.

Ismail SM mengungkapkan tujuan penggunaan strategi ini yakni supaya siswa mempunyai ketrampilan pemecahan masalah pada materi inti serta permasalahan yang dialami dalam keseharian.

Metode small group discussion diskusi terdapat kemungkinan tidak efektif dalam menampilkan informasi baru dalam hal siswa telah secara sadar mendapat motivasi. Namun sepertinya diskusi sangat sesuai saat pendidik akan melaksanakan beberapa hal berikut:

1. Memberikan bantuan siswa belajar berfikir berdasarkan sudut pandang sebuah subjek bahasan melalui pemberian praktek berpikir.

2. Memberikan bantuan siswa memberikan penilaian logis dan berbagai bukti terhadap posisi diri sendiri maupun yang lainnya.

3. Memberikan kesempatan siswa dalam menganalisis penerapan sebuah prinsip.

4. Memberikan bantuan siswa belajar sadar terhadap permasalahan serta menganalisis berdasarkan info yang diterima melalui bahan bacaan maupun ceramah.

5. Memanfaatkan berbagai bahan sesama anggota. 
6. Mendapatkan informasi maupun teori yang memberikan komentar cerita rakyat maupun siswa sebelumnya.

7. Meningkatkan motivasi belajar lebih tinggi.

8. Mendapatkan umpan balik dalam waktu dekat terkait pencapaian tujuan tertentu.[4]

Pendidik berperan pada Metode Small Group Sesuai definisi mengajar yakni menciptakan suasana yang mengembangkan inisiatif serta tanggung jawab belajar siswa. sehingga sikap pendidik sebaiknya:

1. Keterbukaan dalam menerima opini siswa.

2. Menerapkan kebiasaan siswa menjadi pendengar saat pendidik maupun peserta didik lainnya berbicara.

3. Memberikan penghargaan atas pendapat yang berbeda.

4. Memberikan toleransi jika terjadi kesalahan serta memberikan motivasi untuk melakukan perbaikan.

5. Menciptakan rasa percaya diri pada siswa.

6. Memberikan feedback pada hasil kinerja pendidik.

7. Tidak mudah memberikan bantuan pada peserta didik.

8. Tidak sungkan memberikan pujian.

9. Tidak menganggap rendah opini maupun hasil karya siswa walopun memiliki kualitas rendah.

10. Memberikan motivasi siswa agar berani salah serta menerima resiko.

[4]

Langkah-langkah penerapan metode small group discussion diantaranya:

1. Membagi kelas dalam beberapa kelompok kecil (maksimal 5 siswa) dengan menunjuk ketua serta sekretaris.

2. Memberikan soal studi kasus (disiapkan oleh pendidik) sesuai Capaian Pembelajaran (CP) serta Kemampuan Akhir yang disusun.

3. Menginstruksikan masing-masing kelompok untuk melakukan diskusi jawaban soal yang diberikan.

4. Memastikan masing-masing peserta ikut andil secara aktif saat diskusi.
5. Menginstruksikan masing - masing kelompok melalui juru bicara yang ditentukan untuk memaparkan hasil diskusi pada forum kelas.

6. Mengklarifikasi, menyimpulkan serta tindak lanjut (Pendidik).

[4]

Langkah penerapan Metode Small Group Discussion antara lain:

1. Pendidik menyajikan masalah yang kemudian didiskusikan serta memberikan pengarahan secukupnya terkait cara penyelesaiannya. Inti masalah yang akan dibahas dapat dipilih antara pendidik dan peserta didik secara bersama.

2. Pendidik memberikan pembimbingan kepada peserta didik saat pembentukan kelompok diskusi, menentukan pimpinan diskusi (ketua, sekretaris, pelapor, pengatur tempat duduk, ruangan, sarana)

3. Peserta didik melakukan diskusi pada setiap kelompoknya, pendidik melakukan pemantauan setiap kelompok dan menjaga ketertiban, memberikan motivasi serta bantuan masing-masing anggota kelompok berpartisipasi secara aktif supaya diskusi lancar.

4. Masing-masing kelompok memberikan laporan hasil diskusi.

[2]

Metode pada kajian ini yakni survei serta kajian literatur. Obyek penelitian yaitu taruna program studi teknika dan nautika AMN Cilacap. Hasil belajar pada ranah psikomotorik diperoleh melalui metode diskusi. Instrumen yang digunakan yaitu menggunakan media google classroom. Pengamatan dilakukan sesuai dengan langkah-langkah penerapan metode small group discussion. Tahap-tahap tersebut terdeskripsi dalam setiap pertemuan perkuliahan melalui google classroom baik pada taruna teknika maupun nautika. 


\section{Hasil dan Pembahasan}

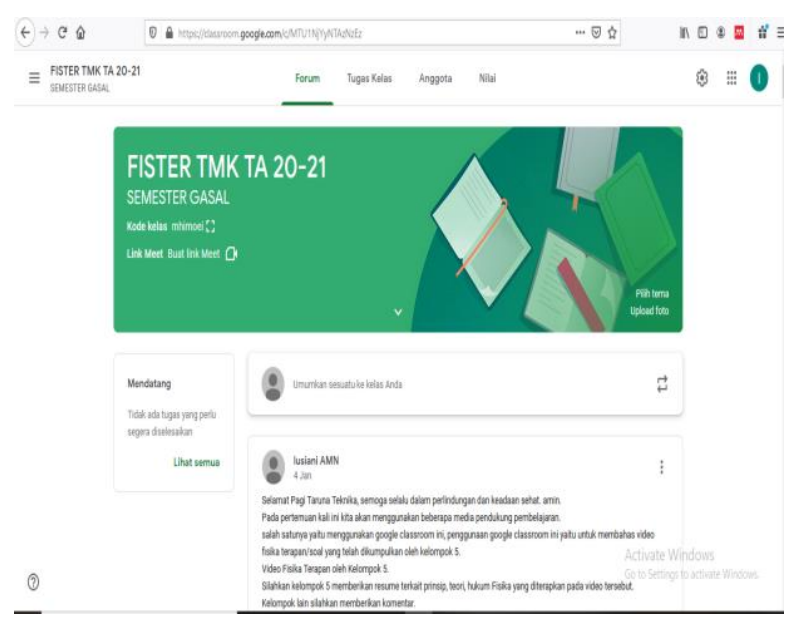

Gambar 1. Tampilan Google Classroom Fisika Terapan Teknika

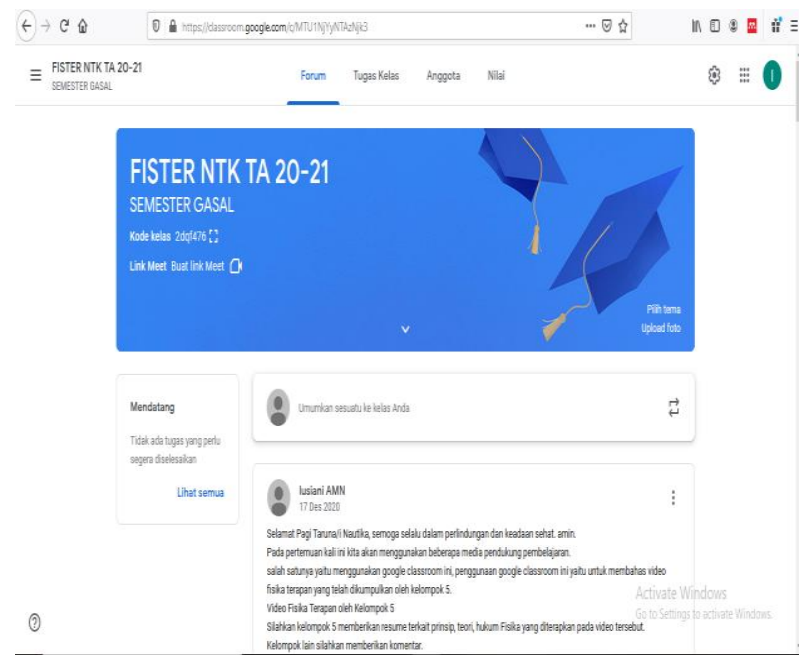

Gambar 1. Tampilan Google Classroom Fisika Terapan Nautika

Langkah-langkah penerapan metode small group discussion diantaranya:

1. Membagi kelas dalam beberapa kelompok kecil (maksimal 5 siswa) dengan menunjuk ketua serta sekretaris.

Dalam kelas teknika, koordinir utama yaitu Komandan Kelas (Danklas) dengan nama taruna Foera-era Alvian Lase. Kelompok dibagi sesuai urut presensi sejumlah kelompok kecil, sedangkan untuk kelas Nautika danklas dengan nama Taruni Firma Nur Lailiyah.

2. Memberikan soal studi kasus (disiapkan oleh pendidik) sesuai Capaian Pembelajaran (CP) serta Kemampuan Akhir yang disusun. yaitu mengupload video fisika terapan di kapal serta mengerjakan soal fisika terapan antara lain: vektor dan volume, daya, dinamika, gerak melingkar, gerak vertikal, fluida, kalor.

3. Menginstruksikan masing-masing kelompok untuk melakukan diskusi jawaban soal yang diberikan.

4. Memastikan masing-masing peserta ikut andil secara aktif saat diskusi.

5. Menginstruksikan masing - masing kelompok melalui juru bicara yang ditentukan untuk memaparkan hasil diskusi pada forum kelas.

6. Mengklarifikasi, menyimpulkan serta tindak lanjut (Pendidik).

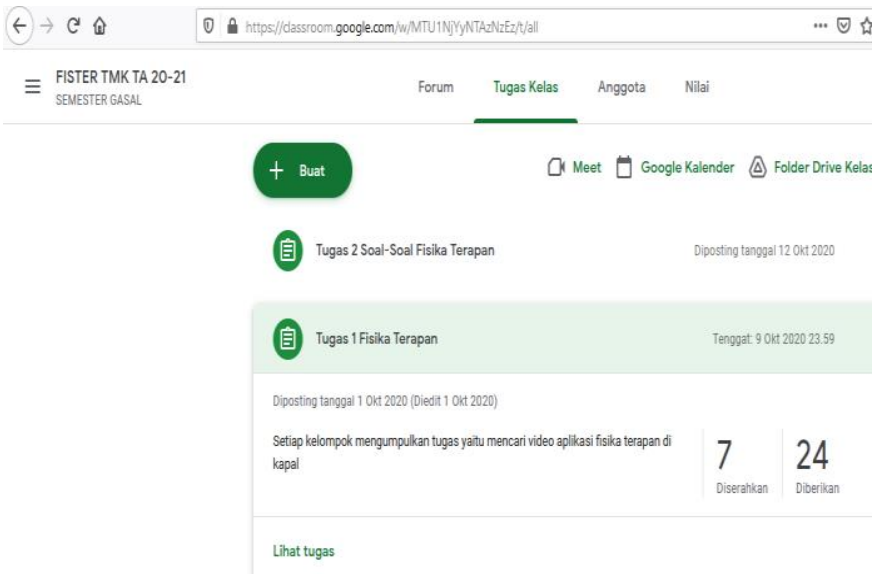

Gambar 3. Pembagian Kelompok dan Pemberian

Studi Kasus (Tugas) Kelas Teknika

Langkah 1 dan 2

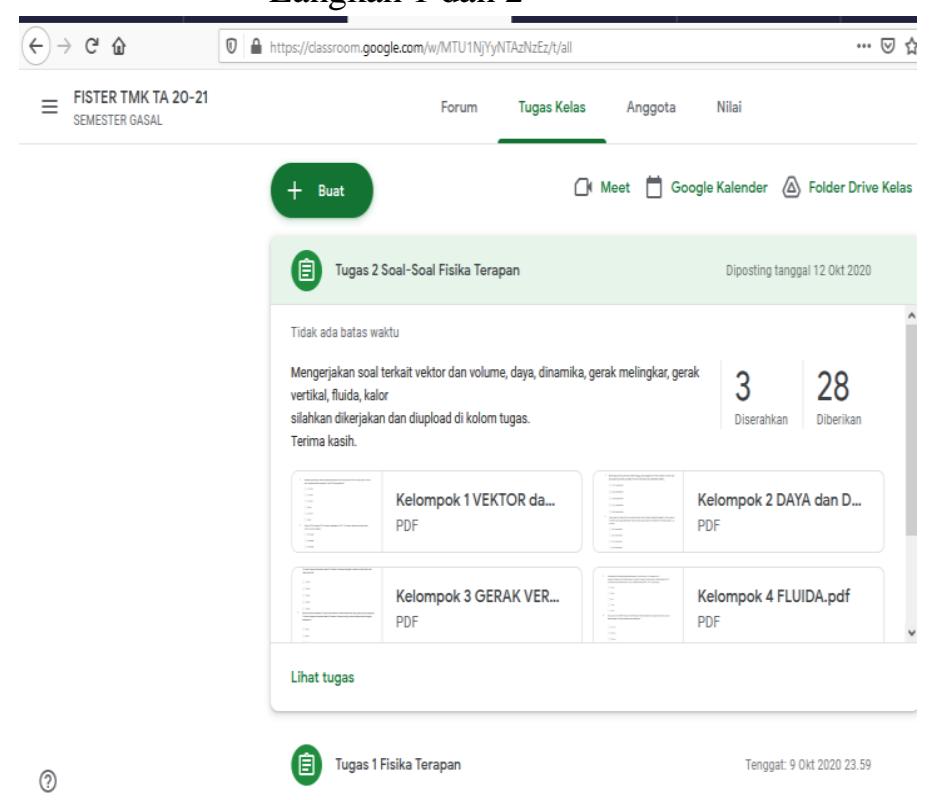

Gambar 4. Pembagian Kelompok dan Pemberian Studi Kasus (Tugas) Kelas Teknika (Lanjutan) Langkah 1 dan 2 
c)

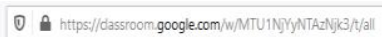

... FISTER NTK TA 20-2 SEMESTER GASAL Forum Tugas Kelas Anggota Nilai

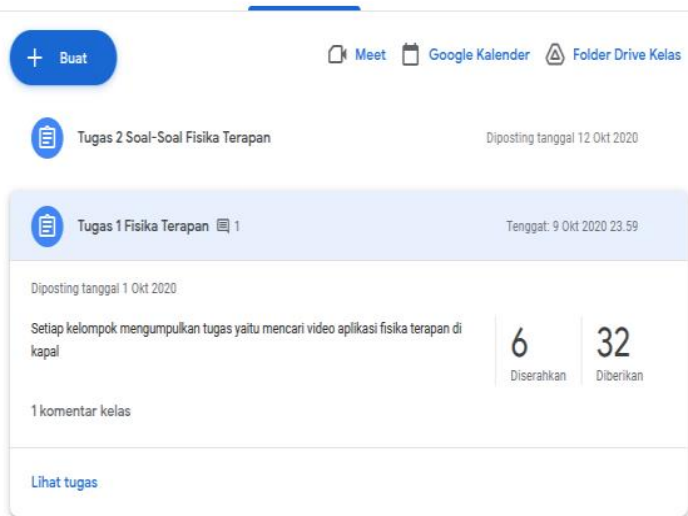

Gambar 5. Pembagian Kelompok dan Pemberian

Studi Kasus (Tugas) Kelas Nautika Langkah 1 dan 2

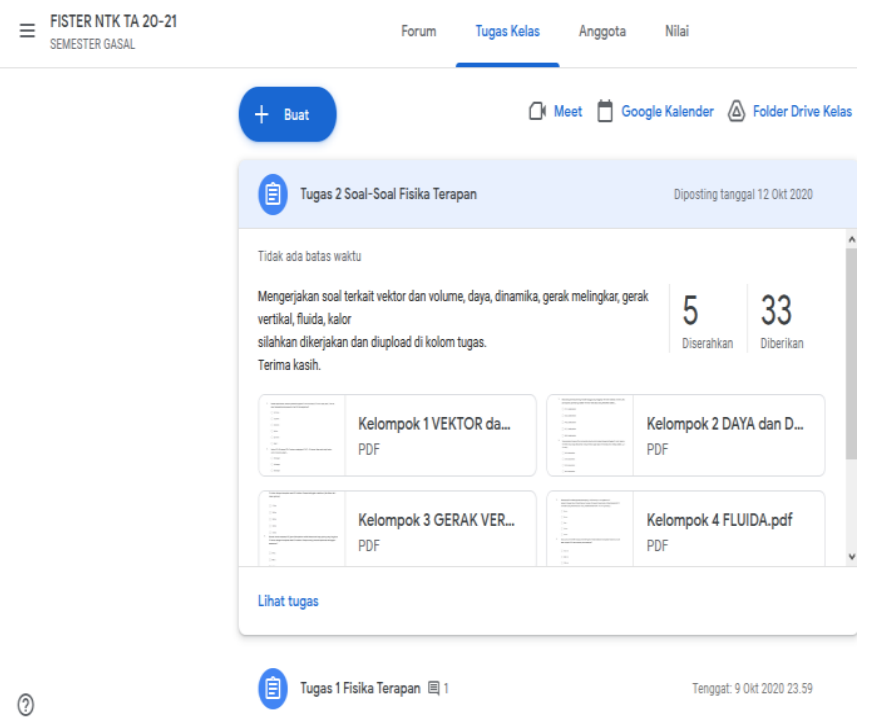

Gambar 6. Pembagian Kelompok dan Pemberian Studi Kasus (Tugas) Kelas Nautika (Lanjutan) Langkah 1 dan 2

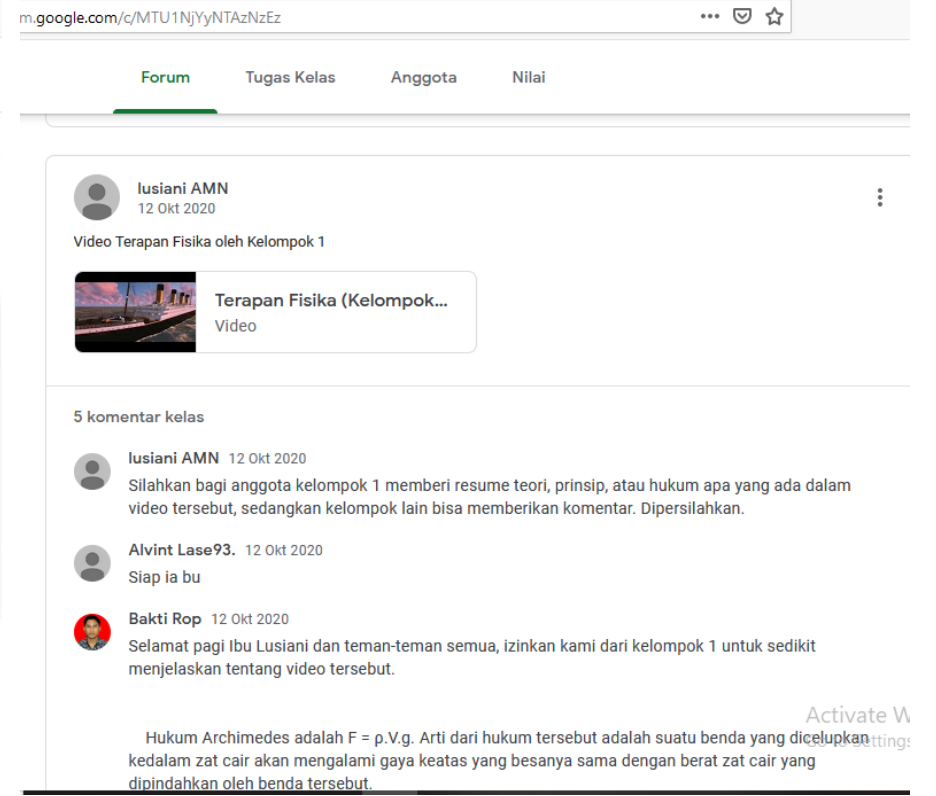

Gambar 7. Pembahasan Studi Kasus Kelas Teknika

Langkah 3, 4 dan 5

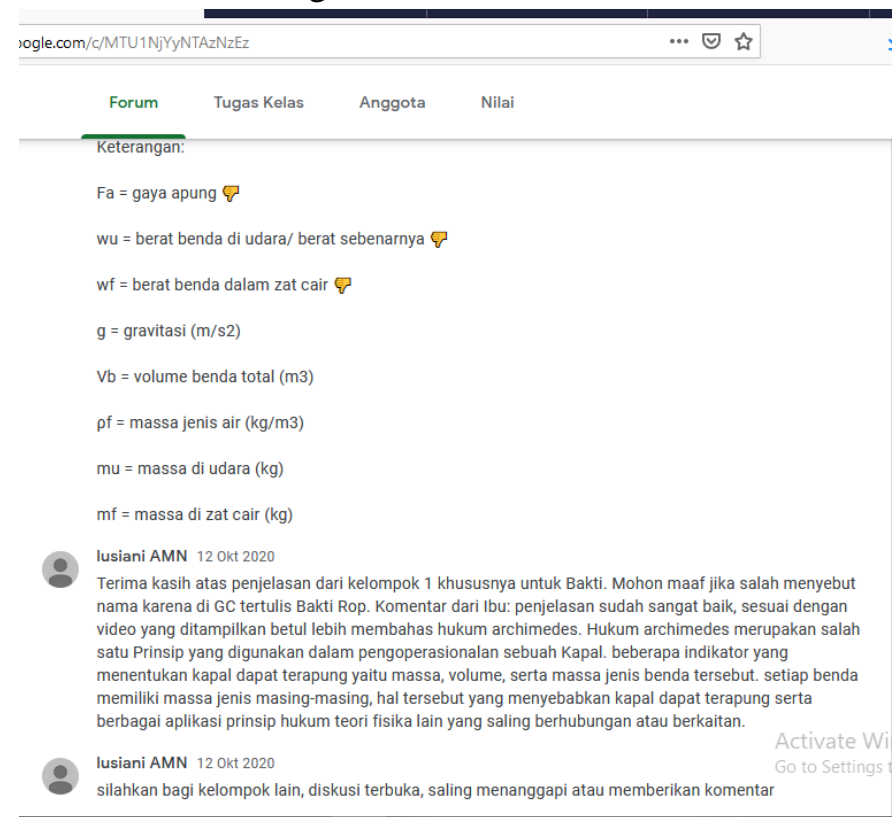

Gambar 8. Klarifikasi Kelas Teknika Langkah 6. 


Tusiani AMN
23 Nov 2020 Tugas Kelas Anggota Nilai
PDF

Gambar 9. Pembahasan Studi Kasus Kelas Teknika (Lanjutan)

Langkah 3, 4 dan 5

Gilang Meilanda Kurniawan 23 Nov 2020
Selamat siang Ibu Lusiani, selamat siang semua teman teman semoga selalu sehat
Gilang Meilanda Kurniawan 23 Nov 2020
Saya atas nama
Nama : Gilang Meilanda Kurniawan
Nit : 2011528
Prodi : Teknika
Kelas : 1 Tugas Kelas
Izin mewakili kelompok 3
Gilang Meilanda Kurniawan 23 Nov 2020
Bahwa dalam nomer 1 dalam gerak vertikal dan energi mekanik itu disebutkan m, dan m itu
menunjukkan atau melambangkan massa dari sebuah benda, dan Vo itu melambankan kecepatan awal
pada gerak sebuah benda
Gilang Meilanda Kurniawan 23 Nov 2020
Sekian dan terimakasih atas waktu dan tempatnya, jika ada tutur kata yang kurang berkenan saya
memohon maaf yang sebesar besarnya

Gambar 10. Pembahasan Studi Kasus Kelas

Teknika (Lanjutan)

Langkah 3, 4 dan 5

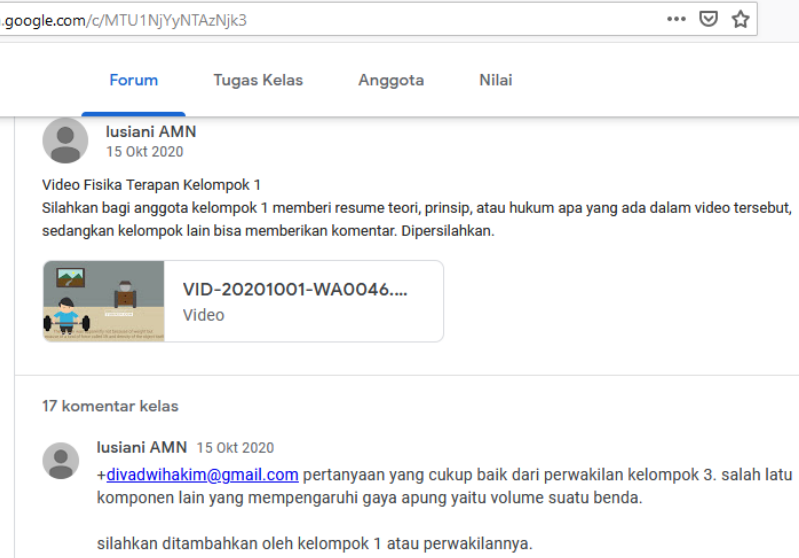

Gambar 11. Pembahasan Studi Kasus Kelas

Nautika

Langkah 3, 4 dan 5

Forum Tugas Kelas Anggota Nilai
17 komentar kelas
Marcellino Excel verjinan 15 okt 2020
Siap sudah melihat vidionya bu
Izin bertanya bu.
Bagaimana sebuah kapal selam mendapatkan udara agar kapal kembali mengapung,apakah sudah ada
udara yg di sediakan atau bagaimana,dan bagaimana sistem pertukaran air dan udara pada saat kapal
selam akan menyelam atau akan mengapung ke atas.
Saya Marcellino Excel Verjinan
NIT 2031239
Prodi Nautik
TERIMAKASIH
Marcellino Excel verjinan 15 Okt 2020
Dari kelompok 4
lusiani AMN 15 okt 2020
baik Marcelino. namun ibu sebelumnya minta kelompok 1 untuk memberikan resume sesuai dengan
yang ibu sampaikan tadi di awal
lusiani AMN 15 okt 2020
setelah ada resume, baru kelompok 1 memberikan jawaban atas pertanyaan dari anggota kelômpiokate Wi
lain. sehingga sistem perkuliahan hari ini melalui diskusi antar kelompok.

Gambar 12. Pembahasan Studi Kasus Kelas Nautika (Lanjutan)

Langkah 3, 4 dan 5 


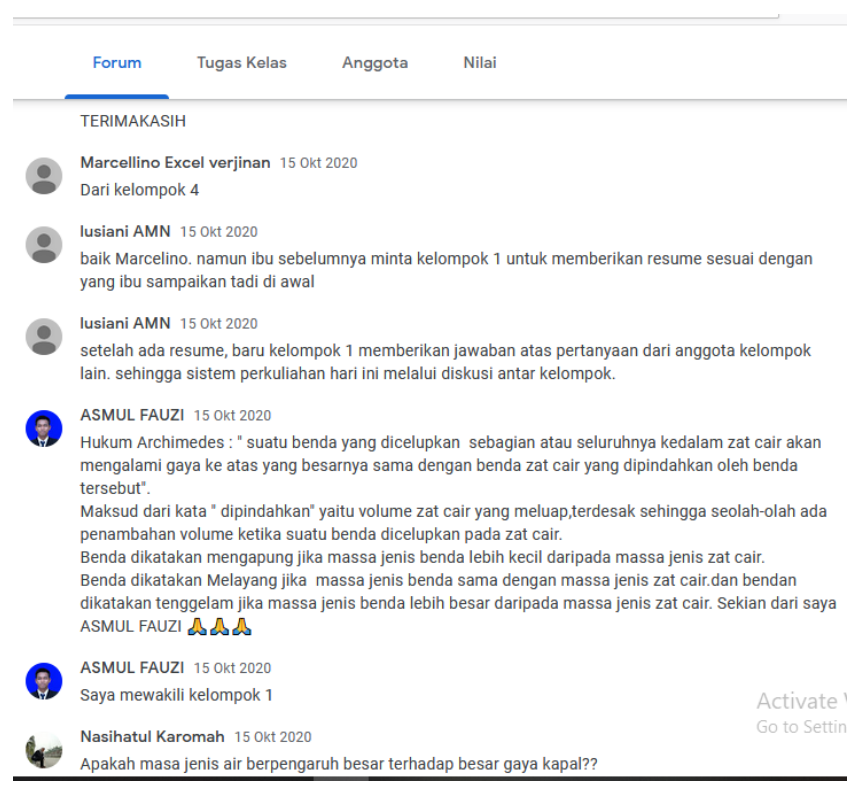

\section{Gambar 13. Pembahasan Studi Kasus Kelas} Nautika (Lanjutan)

Langkah 3, 4 dan 5

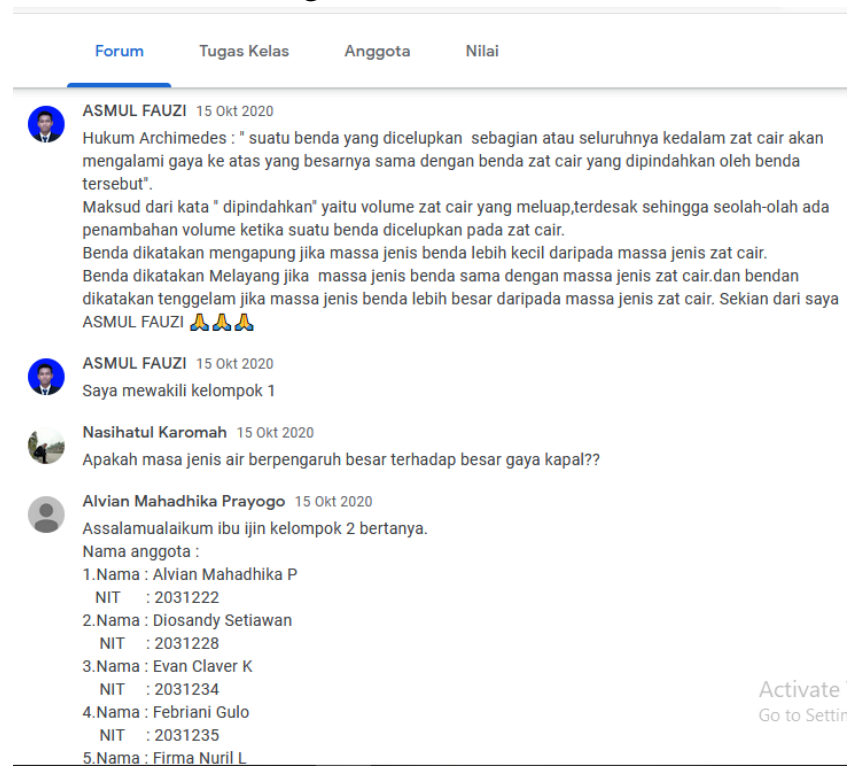

\section{Gambar 14. Pembahasan Studi Kasus Kelas} Nautika (Lanjutan)

Langkah 3, 4 dan 5

\section{Forum Tugas Kelas Anggota Nilai}

6.Nama : Odieli Lahagu
NIT : 2031245
7.Nama : Richard Velia takumansang
NIT : $: 2031251$

7.Nama : Richard Velia takumansang
NIT : 2031251

Apakah hukum Archimedes hanya diterapkan di kapal saja?jika tidak sebutkan contoh benda yg menggunakan hukum Archimedes selain kapal?

Sekian terimakasih.

Diva dwi Hakim al-fikri 15 okt 202

Mohon ijin bu,untuk bertanya, Dalam hukum archimedes, selain dari massa jenis benda dan massa jenis zat cair serta tekanan dr udara yang ada di dalam benda, adakah komponen lain yang bisa mempengaruhi daya apung suatu benda jika di celupkan ke dalam suatu zat cair?

Saya diva dwi hakim alfikri,mewakili kelompok $3 \Omega$

Asty emiliany 15 okt 2020

Ijin menjawab .saya Emiliani Asti Mama mewakili kelompok 1 untuk menjawab pertanyaan kelompok 2 ,

Jadi baik Hukum Archimedes tidak digunakan hanya dikapal saja .. tetapi bisa digunakan seperti pada : Balon udara ,hidrometer, jembatan Panton, jembatan apung dan masih banyak lagi ... Saya mengambil contoh Balon udara

Balon udara dilisi dengan gas dengan massa jenis udara disekitarnya.Dengan perbedaan massa jenis tersebut dapat membuat balon udara mendapatkan gaya angkat ke atas. Sehingga balon udara dapat terbang seperti pesawat.

Hal itu memanfaatkan adanya gaya keatas yang timbul karena adanya perbedaan massa jenis zat...

Sekian dan terimakasih $\Omega \omega \Omega$

Gambar 15. Pembahasan Studi Kasus Kelas

Nautika (Lanjutan)

Langkah 3, 4 dan 5

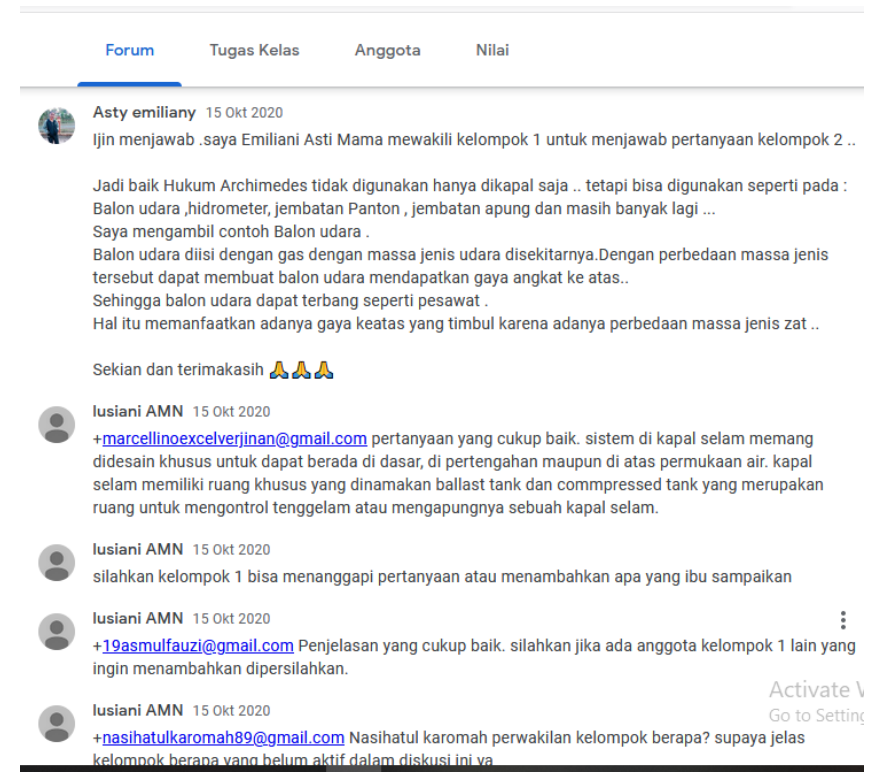

Gambar 16. Klarifikasi Kelas Nautika Langkah 6 


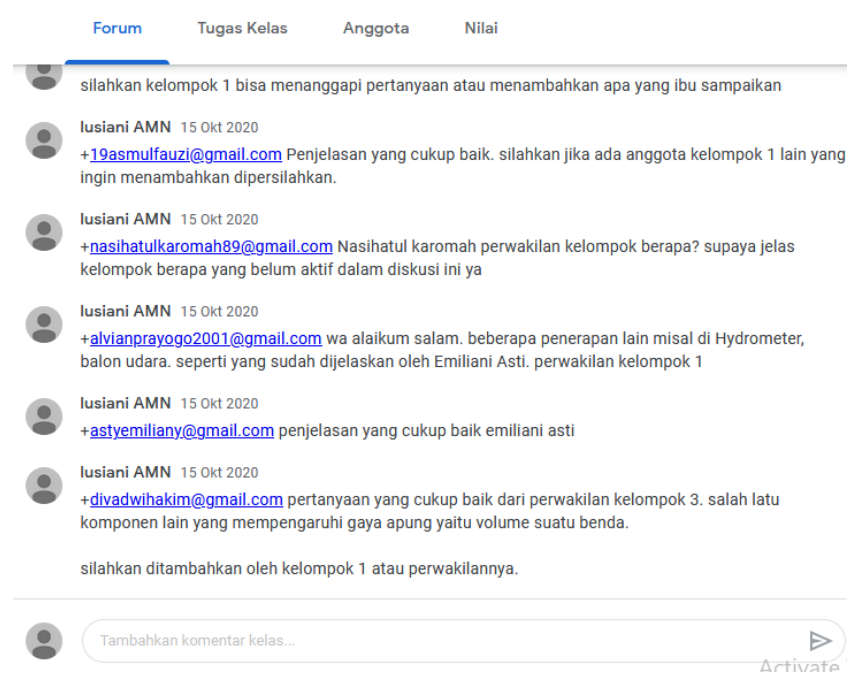

Gambar 17. Klarifikasi Kelas Nautika Langkah 6

Berdasarkan tampilan pada setiap gambar, dideskripsikan langkah small group discussion pada pembelajaran fisika terapan teknika nautika. Langkah 1 sampai 6 terlihat pada gambar 1 hingga 17. Pada kelas Teknika terlihat pada gambar 3, 4, 7, 8, 9, 10. Sedangkan pada kelas Nautika terlihat pada gambar 5, 6, 11, 12, 13, 14, 15, 16, 17. Pembelajaran fisika terapan pada kelas Nautika lebih antusias dan aktif menggunakan small group discussion, sedangkan pada kelas Teknika terlihat standar (pada umumnya).

\section{Kesimpulan}

Setelah dilakukan analisis serta pembahasan, disimpulkan metode student centered learning tipe small group discussion dalam pembelajaran fisika terapan taruna teknika nautika dapat diterapkan sesuai dengan 6 langkah dalam small group discussion.

\section{Ucapan terima kasih}

Penulis mengucapkan terima kasih atas Akademi Maritim Nusantara atas dukungan finansialnya pada penelitian ini dan Taruna Teknika serta Nautika atas kesediaannya sebagai obyek penelitian ini serta dukungannya.

\section{Daftar Pustaka}

[1] Z. Zuriati, "Penerapan Metode Small Group Discussion Dalam Pembelajaran Pendidikan Agama Islam: Dampak Terhadap Peningkatan Prestasi Belajar Peserta Didik
Kelas X Sma," SOSIOHUMANIORA J. Ilm. Ilmu Sos. dan Hum., vol. 4, no. 1, pp. 71-77, 2018, doi: 10.30738/sosio.v4i1.2545.

[2] A. Christiani and Mintohari, "Penerapan Metode Small Group Discussion dengan Model Cooperative Learning untuk Meningkatkan Hasil Belajar Siswa Sekolah Dasar," J. Penilitian Pendidik. Guru Sekol. Dasar, vol. 2, no. 2, pp. 1-11, 2014.

[3] H. Hardiansyah, "Penggunaan Model pembelajaran Small group Discussion Untuk Meningkatkan Hasil Belajar IPS Terpadu Di MTS," J. Pendidik. Dan Pembelajaran Khatulistiwa, 2014.

[4] N. W. Sulistyowati, "Implementasi Small Group Discussion Dan Collaborative Learning Untuk Meningkatkan Prestasi Belajar Mahasiswa Program Studi Pendidikan Akuntansi Ikip Pgri Madiun," Assets J. Akunt. dan Pendidik., vol. 5, no. 2, p. 173, 2017, doi: 10.25273/jap.v5i2.1197. 